\title{
Development model for competency improvement and national vocational qualification support frames in automotive technology
}

\author{
Muhammad Nurtanto ${ }^{1}$, Herminarto Sofyan ${ }^{2}$, Pardjono Pardjono ${ }^{3}$, Suyitno Suyitno ${ }^{4}$ \\ ${ }^{12,3}$ Technical and Vocational Education, Graduate School, Yogyakarta State University, Indonesia. \\ ${ }^{1}$ Department of Mechanical Engineering Education, Faculty of Teacher Training and Education, \\ Universitas Sultan Ageng Tirtayasa, Indonesia. \\ ${ }^{4}$ Department of Automotive Engineering Education, Faculty of Teacher Training and Education, \\ Universitas Muhammadiyah Purworejo, Indonesia
}

\begin{tabular}{l} 
Article Info \\
\hline Article history: \\
Received Dec 16, 2019 \\
Revised Feb 5, 2020 \\
Accepted Feb 24, 2020 \\
\hline Keywords: \\
Competence dimensions \\
Competence test \\
Competency test model \\
Development \\
Engine tune up-injection
\end{tabular}

Article Info

Revised Feb 5, 2020

Accepted Feb 24, 2020

\section{Keywords:}

Competence test

Engine tune up-injection

\begin{abstract}
BNSP technical competence gets high legality on the side of the industry, while not all test participants can acquire it. Until now, studies that discuss relevant competency test models on automotive engine technology are still limited, not specific or even non-existent. The objective of this research is to produce a Competency Test Model for Engine Tune Up-System Injection and determine the characteristics after the model is applied. The subject of development consists of assesses (vocational education graduates, workers and educators), experts, and assessors from related Professional Certification Institutions (LSP). Instrument validation was conducted through expert judgment and feasibility trials. Reliability tests were performed using alpha and interrater coefficient analysis. The results of the test analysis include (1) competency test model assessment using the CBA approach; (2) competency dimension elements in instruments development are in the form of TS, TMS, CMS, EMS, and JRES; and (3) the characteristics of competency assessment include equipment verification of adequacy, avoiding impartiality, meeting requirements, transparent and accounTable, and able to produce recommendations as "competent" and "non-competent". The obtained findings showed that the developed competency test model could be used as a reference for use in vocational education.
\end{abstract}

This is an open access article under the CC BY-SA license.

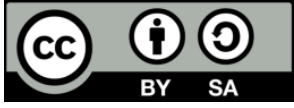

\section{Corresponding Author:}

Muhammad Nurtanto,

Technical and Vocational Education,

Yogyakarta State University,

Colombo Street No.1, Karangmalang, Caturtunggal, Depok Sub-district, Sleman Regency,

Special Region of Yogyakarta, Indonesia.

Email: mnurtanto23@untirta.ac.id

\section{INTRODUCTION}

Vocational education is of particular concern and interesting conversation by academics and researchers globally. Vocational education is considered able to strengthen economic growth and national competitiveness [1]. However, UNESCO-UNIVOC had classified several issues, there are thirteen global issues regarding vocational education including image, access, facilities, planning and administration, curriculum, teaching and learning, teacher qualifications and conditions (salary, living standards, work environment), information and communication technology, finance, testing and certification, and 
the relationship between education and companies. Furthermore, in the context of the Southeast Asian region, SEAMEO VOCTECH identified ten problems faced by TVET including ICT in Vocational Education, curriculum relevance, assessment, research and development, access and equality, management and quality assurance, poverty reduction, life-long learning, decent job promotion, and barriers among formal-informalnonformal [2, 3]. The result of internal dissemination stated Indonesian education has three main problems that are access, quality, and relevance [4, 5]. Vocational education is said to be successful when the clustering of problems that arise gets the right solution. When deeply examined, the main factor that needs to be strengthened is that Human Resources (HR) need to be provided competently and professionally.

Aside from internal problems, Indonesia participates in the challenges of ASEAN Economic Community (AEC) and the ASEAN Socio-Cultural Community (ASCC) which have been declared since December 2015 with the aim of being able to encourage the progress of the ASEAN economy so that it can have positive impacts on joint economic progress. The declaration introduced new problems where labor transfer between countries would take place freely, while Indonesian society is not yet ready in education, foreign language skills and skills certification [6]. Trust is given to Vocational Education by establishing schools massively. This is with hopes that vocational education is able to prepare qualified human resources, improve unemployment rates, and be able to compete in the AEC, as well as other ASEAN countries [7], of course, the problems are similar. The conclusion is that Vocational Education must be able to acculturate itself as what is needed by the industry in terms of competence qualifications required in accordance with the skill program. This has become a new policy for competency-based Vocational Education and Training $[8,9]$ which can be accounted for.

Competence will not be far from the national qualifications' framework or a measurable framework often called KKNI. In their period [10] had designed work competency training. Furthermore, this work was followed by [11] and became part of the learning curriculum [12] in improving competency-based performance. Simply stated, competence is the ability to do work properly [13]. According to [14] emphasizes that "graduate competency is the qualification of the graduate's abilities"; (Manpower Act, Number 13, (2003a) "individual work abilities include aspects of knowledge, skills, and work attitudes according to standards" [13] as well as personal characteristics of a person. Competencies, as mentioned above, have been detailed in the revised 2013 curriculum changes. The approach needed is based on National Vocational Qualifications (NQV) [15] as the basis for competency standards. furthermore, each school must establish a $1^{\text {st }}$ party Professional Certification Agency (LSP) as support for competent graduates [1] reveals that competency is a measure or standard for a person to work. The journey of implementing the revised 2013 curriculum and forming the LSP is still far from the standard. The high number of teachers who have not been licensed has become an obstacle for them to establish LSP, even more, the learning process is less directed or measureable according to industry expectations.

Full attention should be given to teaching staff, they must commit to having a competency certificate as mandated by BNSP [16]. Until currently, at the end of final graduation, students are tested, namely the Vocational Competency Test (UKK) as a graduation requirement. However, the implementation in each school still has not employed the same model, meaning that the implementation is based on the condition of those respective schools. Of course, the results achieved will also be varied. Problems arise if these tests are conducted by educators who do not have special experience in their field or certificate recognition. Of course, the impartiality of the assessment can be said to be very high. Thus, the problem is to obtain a test standard that can be carried out by anyone and the results are not much different from the justified assessment principles.

The findings from UKK implementation in Banten province are as follows: (a) it was found that the implementation of UKK was assessed by internal educators without higher technical competence; (b) it was found that the implementation of the UKK was assessed by internal educators and the industry was involved in a number of participants, and (c) it was found that the implementation of UKK from $1^{\text {st }}$ party LSP were technical experts and did not have methodological competence. Based on the field study, it was concluded that it is important that there was a test model concept with national recognition standards with assessment principles. The renewal of the research on the development of the competency test model gets double output, where UKK is administratively fulfilled and it gets technical recognition and solves the competency gap problem [17] which in other words, corresponds to the vocational relevance in education [8].

Planning the competency test model is focused on the Engine Tune-Up Injection System (ETU-SI) competence. The consideration is that this subject has complex competency that contains several subcompetencies from various fields, namely engine, electrical and basic competencies. In addition, ETU-SI is an automotive technology that is applied in various vehicles today and the industry requires these skills. The model approach is based on the KKNI and LSP reference standards. The stages of competency testing 
refer to [18] namely (a) setting of goals; (b) collection of evidence; (c) comparison of evidence with objectives, and (d) opinion information (content or not yet competent).

The competency test assessment method uses the CBA approach [19] including: (1) restricted and open-ended tests, (2) oral assessment, (3) performance assessment, (4) works-bases assessment. Restricted and open-ended tests are conducted through written tests, both in the form of multiple-choice questions and essays tailored to the competency units in the test cluster. The objective is to measure knowledge competence. The oral assessment is used to determine the attitudes and behaviours, it is carried out by the dialogue with test participants. The performance or Product assessment is a form of test that involves test participants working directly or through work simulations. This method will provide information holistically and direct test takers towards knowledge and skills including the ability to work productivity. Work-based assessment is an assessment model that varies according to the type of work. This assessment will provide a comprehensive picture of the performance and test the participant's work functions.

The competency test instrument component contains elements (1) task skills, (2) task management skills, (3) contingency management skills, and (4) job/role environment skills, [20, 21]. Competency test assessment [22] consists of 4 (four) stages, namely: (1) orientation; (2) gathering evidence; (3) evaluation by others; (4) carrying out competency development activities. Furthermore, the instrument model was tested for effectiveness based on aspects: valid, reliable, flexible, fair, objective, systematic and usable. This provides a recommendation that the developed model produces positive arguments for use in vocational education.

\section{RESEARCH METHOD}

Development research used a modified Borg \& Gall model. The development was carried out in Banten Province considering some facts: (1) having sufficient $1^{\text {st }}$ party LSP with $3^{\text {rd }}$ party TUK LSP partner whose adequacy was verified; (2) availability of technical and methodological experts as assessors who have experience in testing and need a new competency test namely ETU-SI; (3) infrastructure that supports the ETU-SI test scheme; and (4) automotive technology competence is limited to a number of people and needs to be obtained for its development. The time of development research is in 2019.

The subject of this development are assessees as many as 20 people consisting of 6 educators, 5 people from workers, and 9 people from vocational school graduates, 3 external assessors ( ${ }^{\text {rd }}$ party LSP) with the characteristics according to Table 1.

Table 1. Instrument construct test by competency assessment experts

\begin{tabular}{cl}
\hline Experts & \multicolumn{1}{c}{ Expertise Description } \\
\hline \multirow{3}{*}{ Expert1 } & The expert is an automotive vocational instructor at the Vocational Training Center for 16 years. He has \\
& senior competence in the automotive field with 40 competency units. Member of the Indonesian \\
& Vocational Lecturers and Teachers Association. Also, a Competency Assessors at the Center for \\
& Vocational Training, Competency Assessors at LSP TO, LSP TOP, and is currently active in HR in the \\
& Ministry as well as in international vocational cooperation \\
& The expert is a senior instructor at BBPLK Bandung. Having expertise in the automotive field, especially \\
Expert 2 & $\begin{array}{l}\text { in the field of Engine Tune-Up Injection Systems. Management of Professional Certification Institute for } \\
\text { Automotive Professional Technicians implementing agency at the certification section. Active in }\end{array}$ \\
& automotive interagency partnership, having training experience in Germany. \\
Expert 3 & The expert is an educator from state universities for 5 years. Previously as an educator in a vocational \\
& school for 5 years. Active in automotive research. Joining as a competency assessor.
\end{tabular}

Development data were obtained through two types of instruments [23], namely the assessment instrument and the development instrument. Instrument assessment data was a cognitive achievement in the form of the restricted test; psychomotor, and affective tests in the form of performance assessment and assessment of practical knowledge and abstract skills in the form of extracting evidence through oral assessment.

The instrument construct test was conducted through competency assessment experts, ETU Injection Systems experts, and practitioners. This was intended to obtain uniform input and reliable instruments. The developed instrument was applied empirically and theoretically proved its suitability with the construct specifications using factor analysis.

Validity and reliability analysis of the assessment instrument especially the written test in the normal reference required restricted test measuring instrument [24]. Measuring instruments should meet the level of difficulty, reliability, validity, and differentiating power, while in the development of this instrument, some criteria are used as a reference. The reliability level was calculated using alpha coefficients [25] with (1): 


$$
r=\frac{k}{k-1}\left[1-\frac{\sum s^{2} i}{\sum S^{2} t}\right]
$$

$$
\begin{array}{ll}
\mathrm{r} & =\text { reliability coeefficient } \\
\mathrm{k} & =\text { item numbers } \\
S^{2}{ }_{i} & =\text { item variant } \\
S^{2}{ }_{t} & =\text { total variant }
\end{array}
$$

The reliability testing of the instrument criteria uses the interrater coefficient analysis, which is to see the consistency between assessments in giving ratings to the instrument sheets. Measuring the level of interrater reliability on performance assessments and oral assessments used Cohen's Kappa coefficient (K) and percentages of agreements. Cohen's Kappa. Coefficient equation ( $\mathrm{K}$ ) according to [26] is as follows (2):

$$
\mathrm{K}=\frac{\sum f_{0}-\sum f_{e}}{N-\sum f_{e}}
$$

$\mathrm{K}=$ agreement level of assessment

$f_{0} \quad=$ frequency of observations

$f_{e} \quad=$ expected frequency

$\mathrm{N} \quad=$ the number of assessed items

The lower limit of the reliability coefficient for a good test is 0.70 (Educational measurement, 3rd ed, 1989). Next, a descriptive analysis of the test variables and recommendations from the results of the test implementation are then performed.

\section{RESULTS AND DISCUSSION}

The development of competency test models in the ETU-SI scheme began with observations in industry, training centres, LSPs and TUKs at SMK N 1 Cilegon. Observation conducted on the automotive sector in Banten as a place for graduates. Observation of the training centre was conducted by experts at the Center for Job Training (BBLK) in the automotive field in Bandung as a consideration of the implementation of competency tests. Observation of assessors' associations through $3^{\text {rd }}$ party LSP was conducted. Observations were also made at TUK when $3^{\text {rd }}$ party LSP partners at SMK N 1 Cilegon.

The observation results from stakeholders regarding the development of ETU-SI competency assessment models are as follows: assessment expected by the industry includes KKNI competencies consisting of general works and expert work with knowledge, psychomotor also work and environmental affective competencies [27-29]. Those competencies include (a) carrying out components maintenance/servicing KUK.OTO.KR01.001; (b) reading and understanding technical drawings KUK.OTO.KR01.009; (c) measurement tools usage and maintenance KUK.OTO.KR01.010; (d) compliance to occupational health and safety procedures KUK.OTO.KR01.016; (e) usage and maintenance of work equipment and tools KUK.OTO.KR01.017; (f) carrying out manual working operations KUK.OTO.KR01.018; (g) the engine maintenance or service and its components KUK.OTO.KR02.001; (h) the cooling system maintenance or servicing and its components KUK.OTO.KR02.010; (i) engine fuel system maintenance or service KUK.OTO.KR02.014; (j) emission control system maintenance or service KUK.OTO.KR02.020; (k) battery test, maintenance or service and replacement KUK.OTO.KR05.01; (l) the ignition system repair KUK.OTO.KR05.011; (m) engine management system maintenance or service and repair KUK.OTO.KR05.012.

(2) So far, the UKK assessment has been incomplete and only carried out on internal assessors who do not yet have the technical expertise and carried out by educators which results in high impartiality. This results in high test success rates but still being far from industry standards. (3) HR in $1^{\text {st }}$ party LSP SMK $\mathrm{N} 1$ Cilegon didn't have technical experts at ETU-SI while the infrastructure meets the technical validation of the TUK at the time.

Factors related to the assessee in carrying out competency tests include conditions, readiness, and learners' expectations are relatively not ready to be tested by external institutions. In addition, motivation to learn and practice is very low, while the desired expectations are high for having a certificate of technical competence.

The competency test model in the ETU-SI scheme is a competency assessment model that is intended for general public testing, both internal and external and allows the test to be conducted through a portfolio as long as it meets the requirements of test adequacy (13 KUK units of competency). Beginning with the identification of competencies based on the IQF and then developed into the test material. The test material was developed into some evidence collections, namely direct evidence through practice (psychomotor aspects) and in-depth interviews (affective aspects) and the five dimensions of competence: 
task skill (TS), task management skills (TMS), and contingency management skills (CMS), Environmental Management Skills (EMS), and Job Role Environment Skills (JRES). Indirect evidence includes multiplechoice tests (cognitive aspects) for assessment and integrated for assessees' decision making. The assessment instrument [30] is used as a test instrument and the fulfilment of evidence collection as a "competent" or "not competent" recommendation. Each assessment model test kit is equipped with assessment instructions.

Equipment trials were conducted at TUK SMK N 1 Cilegon which have met the verification of the carrying capacity adequacy. The application results of the injection system ETU UJK model are analyzed to support that the instrument can be used as the standard reference. The assessors as experts in their respective fields gave their opinions on the implementation of the ETU SI competency test. Assessment is based on validity, reliability, feasibility, and effectiveness of the competency tests implementation. The assessment criteria used are divided into 4 scales including (1) very good, score 4; (2) good, score 3; (3) bad, score 2; and very bad, score 1 . The assessment of the test instrument is based on indirect evidence, direct evidence or additional evidence was as shown in Table 2.

Table 2. UJK results validity of restricted test assessment, performance assessment, and oral assessment

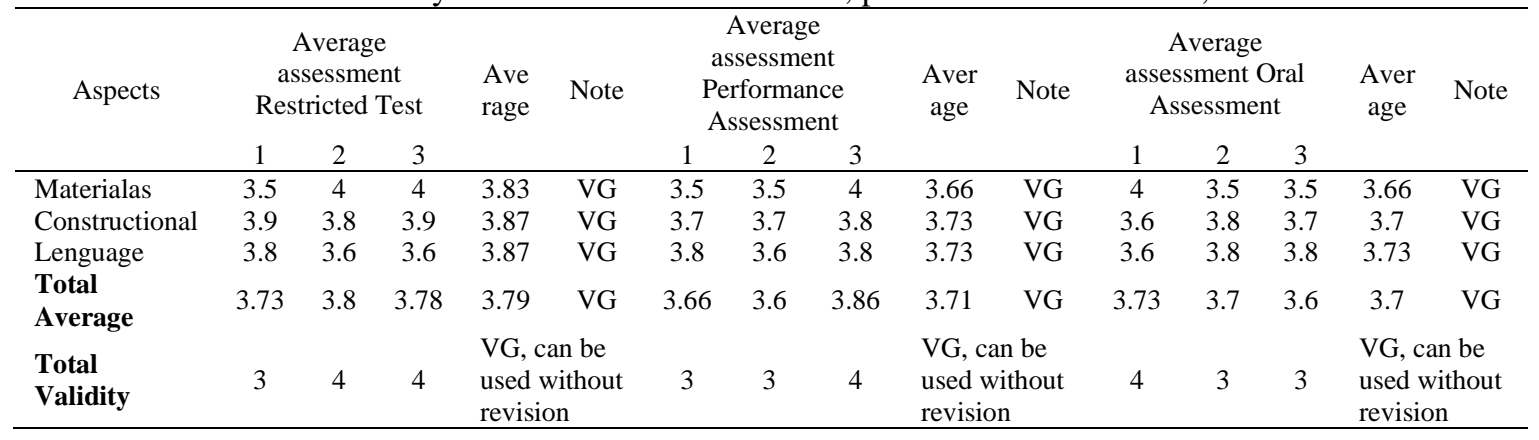

The validation results show that the competency test instrument has met the aspects of the material, constructs and language validity which are very good and can be used for the UJK. Reliability analysis between assessors using Cohen's Kappa coefficient (K) with the calculation results is shown in Table 3.

Table 3. Coefficient ( $\mathrm{K}$ ) between restricted test, performance assessment, and oral assessment

\begin{tabular}{cccccccccc}
\hline \multirow{2}{*}{ Assessor } & \multicolumn{3}{c}{ Restricted Test } & \multicolumn{3}{c}{ Performance Assessment } & \multicolumn{3}{c}{ Oral Assessment } \\
& 1 & 2 & 3 & 1 & 2 & 3 & 1 & 2 & 3 \\
\hline 1 & & 0.928 & 0.680 & & 0.850 & 0.673 & & 0.808 & .755 \\
2 & & & 0.860 & & & 0.821 & & & 1 \\
3 & & & & & & & & \\
& Average $=\mathbf{0 . 8 2 3}$ & & Average $=\mathbf{0 . 7 8 1}$ & $\mathbf{0 . 8 5 4}$ \\
\hline
\end{tabular}

Overall, reliability among assessors are in the high category based on three assessors: (a) the coefficient $(\mathrm{K})$ for multiple-choice tests was 0.823 ; (b) coefficient $(\mathrm{K})$ for the practical test of 0.781 ; and (c) the coefficient $(\mathrm{K})$ for the interview test is 0.854 . The reliability coefficient value of the assessment is in the very good agreement category, so the assessment meets the reliable requirements

The results of sub competency evidence collected in the ETU-SI scheme competency test based on direct evidence, indirect evidence, and additional evidence are as follows, on Table 4.

Table 4. Results of competence evidence collection

\begin{tabular}{lccc}
\hline \multicolumn{1}{c}{ Test Aspects } & C/NC & APK & $(\%)$ \\
\hline Restricted Test & $\mathrm{C}$ & 15 & 75 \\
Total & $\mathrm{NC}$ & 5 & 25 \\
Performance & $\mathrm{C}$ & 20 & 100 \\
Assessment & $\mathrm{NC}$ & 9 & 55 \\
Total & & 20 & 45 \\
Oral Assessment & $\mathrm{C}$ & 12 & 100 \\
Total & $\mathrm{NC}$ & 8 & 60 \\
& & 20 & 40 \\
\hline
\end{tabular}

Int. J. Eval. \& Res. Educ. Vol. 9, No. 1, March 2020: 168 - 176 
It can be explained that the evidence collection based on KUK consisting of Restricted Test, Performance Assessment, and Oral Assessments as a whole is shown in Table 4. In the Restricted Test, the recapitulation results showed that 15 (75.00\%) were declared "Competent" and 5 (25.00\%) were declared "Not Competent ". In Performance Assessment by taking evidence from direct observation, the recapitulation results showed that as many as $11(55.00 \%)$ were declared "Competent" while 9 (45.00\%) were declared "Not Competent". In the Oral Assessment in the form of in-depth evidence collection, it was stated that 12 $(60.00 \%)$ were declared "Competent" while 8 (40.00\%) were declared "Not Competent". The results of the three test aspects $t$ are recapitulated to make recommendations for decisions, shown in Table 5.

Table 5. Recapitulation of ETU scheme injection system competency test results

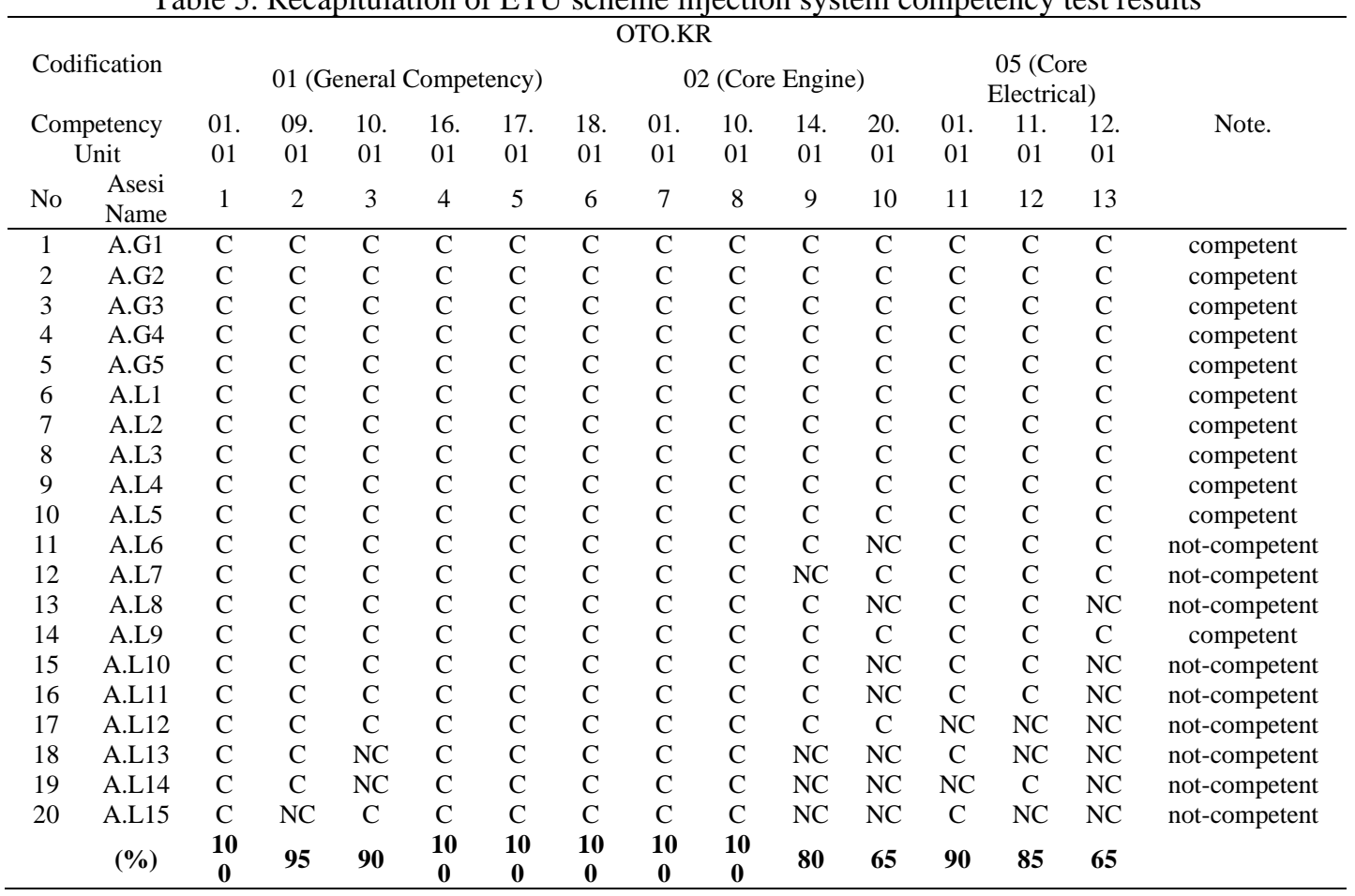

In the recapitulation from Competency Test results based on KUK, there are 7 out of 13 "Not Competent" competency units. 9 out of 20 people experience difficulty in several competency units. Based on the success rate in the competency unit the difficulty levels experienced are as follow (1) OTO.KR02.20.01 emissions control system maintenance and services, as many as 35\% (7 people) are not yet competent; (2) OTO.KR05.12.01 engine management system maintenance and services and improvement as many as 35\% (7 people) are not yet competent; (3) OTO.KR02.14.01 engine fuel maintenance and services as much as $20 \%$ (4 people) are not yet competent; 4) OTO.KR05.11.01 the ignition system improvement as much as 15\% (3 people) not yet competent; (5) OTO. KR05.01.01 batteries test, maintenance and services and replacement and OTO. KR01.10.01 measuring devices usage and maintenance, as many as $10 \%$ (2 people) are not yet competent; and (6) OTO.KR01.09.01 technical drawings reading and understanding, as many as 5\% (1 person) are not yet competent. The competency unit that has the highest level of difficulty is emission control maintenance and service, and also engine management systems maintenance or service and improvement.

The competency test model set on the ETU-SI scheme's effectiveness was tested based on several aspects including valid, reliable, flexible, fair, objective, systematic and usable. The assessment is done by observation on the competency test by six licensed expert assessors. The results of the effectiveness assessment are shown in Table 6.

The effectiveness assessment aspect of the ETU-SI Competency Test model showed that all aspects were in the category of very good. The average of the 7 assessment aspects was 3.74. The most important aspect in the assessment was the objectivity of the competency test model instrument, all assessors gave an average of 4.00. Thus, the instrument proved that there was no participant siding and it was carried out in accordance with the principles of good assessment. 
Table 6. Effectiveness assessment results of the UJK ETU injection system model

\begin{tabular}{cccccc}
\hline \multirow{2}{*}{ Assessment Aspect } & \multicolumn{2}{c}{ Assessment Set Effectiveness } & \multirow{2}{*}{ Average } & \multirow{2}{*}{ Note } \\
& $\mathbf{1}$ & $\mathbf{2}$ & $\mathbf{3}$ & & \\
\hline Valid & 3.45 & 3.38 & 3.36 & 3.40 & Very Good \\
Reliable & 3.67 & 3.61 & 3.77 & 3.68 & Very Good \\
Flexible & 3.80 & 3.77 & 3.80 & 3.79 & Very Good \\
Fair & 4.00 & 3.80 & 4.00 & 3.93 & Very Good \\
Objective & 4.00 & 4.00 & 4.00 & 4.00 & Very Good \\
Systematic & 3.56 & 3.67 & 3.67 & 3.63 & Very Good \\
Usable & 3.80 & 3.80 & 3.60 & 3.73 & Very Good \\
Average & $\mathbf{3 . 7 5}$ & $\mathbf{3 . 7 2}$ & $\mathbf{3 . 7 4}$ & $\mathbf{3 . 7 4}$ & Very Good \\
\hline
\end{tabular}

The model feasibility includes aspects of effectiveness and practicality. The assessment results conducted by 3 assessors are shown in Table 7 .

Table 7. Competency test model assessment results

\begin{tabular}{cccccc}
\hline \multirow{2}{*}{ Assessment Aspect } & \multicolumn{2}{c}{ Model development by assessor } & \multirow{2}{*}{ Average } & \multirow{2}{*}{ Note. } \\
\hline Effectiveness & 1 & 2 & 3 & & \\
Practicality & 3.83 & 3.81 & 3.27 & 3.64 & Very Good \\
Average & 3.80 & 3.60 & 3.20 & 3.53 & Very Good \\
\hline
\end{tabular}

The effective and practical implementation of the model showed a very good average. All planning and assessment procedures were carried out well. Fulfilment of the competency dimensions of task skills (TS), task management skills (TMS), contingency management skills (CMS), Environmental Management Skills (EMS), and Job Role Environment Skills (JRES) were consistent in each test set so that they were practical in competency testing. This showed that the implementation of the ETU-SI competency test was in accordance with the development of the model and was very good.

Competency achievement assessment based on Restricted Test, Performance Assessment, Oral Assessment which includes cognitive, psychomotor, and affective aspects could evaluate a person to obtain legitimacy or recognition. Evidence collection during practice and in-depth interviews are ways to see if someone masters the test scheme. All tests met $13 \mathrm{KUK}$ and were integrated for decision making. In assessment principle, if one KUK is found to be incomplete, then the person is declared to be not competent. This means that the evidence collection integrates all aspects and all competency tests. The overall competency results are as presented in Table 8.

Table 8. Competency achievement statistics

\begin{tabular}{cccc}
\hline Statistics & Restricted Test score & Performance Assessment score & Oral Assessment score \\
\hline Subject & 20 & 20 & 20 \\
Mean & 8.78 & 7.57 & 8.36 \\
Median & 8.91 & 8.08 & 8.75 \\
Mode & 9.21 & 8.19 & 8.57 \\
Variance & 3.52 & 0.35 & 2.18 \\
Range & 7.50 & 3.47 & 5.20 \\
Minimum & 7.5 & 6.5 & 4.0 \\
Maximum & 10.00 & 10.00 & 10.00 \\
\hline
\end{tabular}

Overall review, the assessment with the highest level of success is the Restricted Test $<$ Performance Assessment <Oral Assessment. The score on the Restricted Test shows that the mean <median <mode. Scores on Performance Assessment see the mean <median <mode. Scores on Oral Assessment look mean $<$ median> mode. Scores on Performance Assessment have a mean of 7.57 lower than Oral Assessment 8.36 and Restricted Test 8.78. This is because practice tests consist of complex competencies and one must understand all work instructions [31]. Most assessees do not really master the competency unit of the emission control system and the engine management system (EMS). These are considered technological systems with new understanding and are not taught in-depth. Of course, this brings difficulties during the practicum given that the components are very complex and assessees do not understand the performance of each component. This has caused the not-competent result on the UJK ETU injection system. In addition, it becomes an input to the curriculum in vocational schools [32] that the emission system and EMS need to 
be taught and be given special training for students in vocational schools. Several developments have introduced components to the injection system and EMS and need to be improved with anticipation of damage using a scan tool or without tools. This condition is the most important part of this competency.

The competency test model development using the CBA approach has several characteristics during the implementation of the competency test and instrument assessment, including evidence collection from various aspects through testing, becomes a basic principle for assessors in recommending assesses, especially in $1^{\text {st }}$ party LSP, $2^{\text {nd }}$ party LSP and $3^{\text {rd }}$ party LSP to maintain the quality of certification; the assessment model must integrate all tests and must not see any of the tests declared competent; implementation of competency tests should avoid subjectivity and impartiality, namely the fair and objective assessment process; the recommendations can be accounted for and have traceability if they are appealed.

\section{CONCLUSION}

The construct of the ETU-SI competency test instrument model consists of restricted "multiple choice" tests, performance assessments "practice tests", and oral assessments "interview tests." Competency dimension elements in developing instruments are task skills (TS), task management skills (TMS), and contingency management skills (CMS), Environmental Management Skills (EMS), and Job Role Environment Skills (JRES). The characteristics of competency assessment include: verification of adequacy or appropriateness of equipment, avoiding impartiality, meeting requirements (validity, reliability, flexible, fair, objective, systematic, and usefulness), transparent and accounTable, and stating "competent" and "not competent" recommendations ". This study has produced a competency test model that is in accordance with automotive industry standards in ETU-SI technology.

\section{REFERENCES}

[1] R. Maclean and D. Wilson, Eds., International Handbook of Education for the Changing World of Work: Bridging Academic and Vocational Learning. Springer Netherlands, 2009.

[2] P. C. Diep, "Ho Chi Minh City University of Technology and Education, Vietnam," no. 8, p. 19, 2017.

[3] P. Paryono, "Regional qualification frameworks in Southeast Asia: current status, opportunities, and challenges. Paper presented at the International Conference on 'Harnessing Qualification Framework towards Quality Assurance in TVET', Manila, the Philippines," 2009. [Online]. Available: https://www.voced.edu.au/content/ngv\%3A75883. [Accessed: 28-Aug-2019].

[4] C. Logli, "Higher education in indonesia: Contemporary challenges in governance, access, and quality," in The Palgrave Handbook of Asia Pacific Higher Education, C. S. Collins, M. N. N. Lee, J. N. Hawkins, and D. E. Neubauer, Eds. New York: Palgrave Macmillan US, pp. 561-581, 2016.

[5] D. Sulisworo, R. Nasir, and I. Maryani, "Identification of teachers' problems in Indonesia on facing global community," Int. J. Res. Stud. Educ., vol. 6, no. 2, Feb 2016.

[6] R. Lawitta, L. Sihaloho, and J. Arianti, "Vocational high school in Indonesia facing ASEAN Economic Community (AEC)," International Conference on Teacher Training and Education 2017 (ICTTE 2017), 2017.

[7] D. C. Israel et al., "The ASEAN Economic Community and the Philippines: Implementation, outcomes, impacts, and ways forward (full report)," PIDS Discussion Paper Series, Working Paper 2013-01, 2013.

[8] S. Williams and P. Raggatt, "Competence-based Vocational Training Policy: a case study of the decollectivisation of employment relations," J. Vocat. Educ. Train., vol. 48, no. 4, pp. 315-332, Jan 1996.

[9] S. Williams and P. Raggatt, "Contextualising public policy in vocational education and training: The origins of competence-based vocational qualifications policy in the UK," J. Educ. Work, vol. 11, no. 3, pp. 275-292, Oct 1998.

[10] R. Zemke and R. R. Gratz, "The role of theory: Erikson and occupational therapy," Occup. Ther. Ment. Health, vol. 2, no. 3, pp. 45-63, 1982 .

[11] J. W. Burke, Ed., Competency based education and training. London; New York: Falmer Press, 1989.

[12] A. E. Burke, B. Benson, R. Englander, C. Carraccio, and P. J. Hicks, "Domain of competence: Practice-based learning and improvement," Acad. Pediatr., vol. 14, no. 2, Suppl, pp. S38-54, April 2014.

[13] M. Kuruba, Role Competency Matrix: A Step-by-step Guide to an Objective Competency Management System. Springer, 2019.

[14] Indonesia - Law on the National Education System (No. 20/2003). [Online]. Available: https://www.ilo.org/dyn/natlex/natlex4.detail?p_lang=en\&p_isn=84435. [Accessed: 12-Sep-2019].

[15] S. Williams, "Policy failure in vocational education and training: The introduction of National Vocational Qualifications (1986-1990)," Educ. Train., vol. 41, no. 5, pp. 216-226, 1999.

[16] E. Sulistyaningsih, Effectiveness, efficiency and impact of Indonesia's apprenticeship programme, 2010.

[17] R. Oczkowska, S. Wiśniewska, and Paweł Lula, "Analysis of the competence gap among vocational school graduates in the area of smart specialization in Poland," Int. J. Qual. Res., vol 11, no 4, 2017.

[18] The International Labour Organization and the quest for social justice, 1919-2009. [Online]. Available: https://www.ilo.org/global/publications/ilo-bookstore/order-online/books/WCMS_104643/lang--en/index.htm. [Accessed: 12-Sep-2019]. 
[19] A. Gonczi, "Developing a competent workforce. Adult learning strategies for vocational educators and trainers," National Centre for Vocational Education Research, pp. 252 Kensington Road, Leabrook, South Australia 5068, Australia., 1992.

[20] G. Hawke and I. Cornford, "Australian Vocational Education Policy Change: But Will the revolution improve the quality of training?" Aust. N. Z. J. Vocat. Educ. Res., vol. 6, no. 2, pp. 104-34, 1998.

[21] T. Kuncoro, E. S. Santoso, S. Sudomo, and A. Dardiri, "The competency requirement of education profession skill engineers refers to the regional model competency standards (RMCS) in The Construction Industry," 1st International Conference on Vocational Education and Training (ICOVET 2017), 2017.

[22] J. Schoonenboom et al., "Supporting life-long competence development using the TENCompetence infrastructure: a first experiment," Int. J. Emerg. Technol. Learn. IJET, vol. 3, no. 0, pp. 53-59, July 2008.

[23] J. C. Liu, K. S. John, and A. M. B. Courtier, "Development and validation of an assessment instrument for course experience in a general education integrated science course," J. Geosci. Educ., vol. 65, no. 4, pp. 435-454, November 2017.

[24] A. C. John, "Reliability and validity: A Sine Qua Non for fair assessment of undergraduate technical and vocational education projects in Nigerian Universities," 2015.

[25] R. L. McKinley, "Review of essentials of educational measurement," J. Educ. Meas., vol. 24, no. 2, pp. 182-184, 1987.

[26] B. H. Cohen, Explaining Psychological Statistics. John Wiley \& Sons, 2008.

[27] M. Nurtanto et al., "Information media literacy to improve working concept comprehension of ignition system with contact breaker and problem-based learning," Proceedings of the International Conference of Social Science, Denpasar, Indonesia, 2019.

[28] M. Nurtanto, S. Nurhaji, D. Widjanarko, M. B. R. Wijaya, and H. Sofyan, "Comparison of scientific literacy in engine tune-up competencies through guided problem-based learning and non-integrated problem-based learning in vocational education," J. Phys. Conf. Ser., vol. 1114, November 2018.

[29] M. Nurtanto, H. Sofyan, M. Fawaid, and R. Rabiman, "Problem-Based Learning (PBL) in Industry 4.0: Improving learning quality through character-based literacy learning and life career skill (LL-LCS)," Univers. J. Educ. Res., vol. 7, no. 11, pp. 2487-2494, November 2019.

[30] S. Cervai, L. Cian, A. Berlanga, M. Borelli, and T. Kekäle, "Assessing the quality of the learning outcome in vocational education: the Expero model," J. Workplace Learn., vol. 25, no. 3, pp. 198-210, Jan 2013.

[31] K. von Treuer and N. Reynolds, "A competency model of psychology practice: Articulating complex skills and practices," Front. Educ., 2017.

[32] S. Ersoy and H. Küçük, "The effect of a new teaching methodology on learning performances of automotive mechatronics students," Procedia - Soc. Behav. Sci., vol. 2, no. 2, pp. 310-316, 2010. 